\title{
Investment in human capital as the basis for the country's economic growth
}

\author{
Ekaterina Nezhnikova ${ }^{1, *}$ \\ ${ }^{1}$ Peoples Friendship University of Russia (RUDN University), 6, Miklukho-Maklaya Street, 117198, \\ Moscow, Russia
}

\begin{abstract}
A key factor in modern economic growth is investment in people and in the development of human capital, as evidenced by the experience of many countries. Investments in human capital create conditions for sustainable economic growth, constant adaptation of the socio-economic structure to new areas of scientific and technological progress. In addition, investments in people form demand in many adjacent sectors, thereby causing a significant multiplier effect. Currently, the role of the state in this area is quite large. The role of the state is especially great in the most important spheres of the formation of human capital - in the field of education, health care and the allocation of research.
\end{abstract}

\section{Introduction}

The theory of human capital proceeds from the assumption that capital is a certain stock of goods that, by accumulating, brings income through investment. Therefore, the theory of human capital implies a certain relationship between the level of education, physical health, quality of education, the volume of production experience and wages, and as a result, the accumulation of human capital in a country directly affects the level of competitiveness of its economy and economic growth. The application of the term investment to the costs of creating a qualitatively new workforce contributed to the departure from the perception of these costs as consumer. These costs were recognized as productive, as investing in a person brings a tangible long-term economic effect.

This study proposes to highlight the following types of investment in human capital: - expenses for education - including general and special, formal and informal, on-the-job training;

- health care costs, consisting of the costs of disease prevention and medical care; - expenses for scientific research, thanks to which intellectual resources are effectively used that can generate knowledge, turn it into scientific results and advanced technologies, creating the necessary conditions of an institutional, infrastructural and regulatory nature to ensure the development of an innovative economy.

\footnotetext{
* Corresponding author: Nezhnikova_ev@rudn.ru
} 


\section{Education expenses}

Investments in education are recognized by the scientific community as the most common and studied among all types of investing in people. According to UNESCO, about $60 \%$ of the difference in a person's income depends on his level of education, the remaining percentage falls on the remaining factors, including health, innate abilities, etc. In countries with developed economies, stable socio-political systems, people with higher education are more competitive and receive higher wages for their labor and abilities. As a rule, highly qualified educated employees are highly productive, they are more disciplined and organized, improve their skills and experience and work in good faith. There is an understanding that investing in education will ultimately give a return, so any employer is interested in an educated employee. The economically developed countries of the world have achieved their success largely thanks to the support of education. Leading universities are located in the United States, Great Britain, the countries of the European Union, and Japan. Most Nobel laureates come from these countries, budgetary spending on education is considered a priority, hence serious breakthroughs in science and technology. The state and society have long had an understanding that investing in human capital will pay off and make a profit in the long run. The most important condition for the formation of human capital is the development of the education system. In the Russian Federation, education is one of the leading branches of the social sphere. An important degree of human capital formation is higher professional education aimed at training and retraining specialists of the appropriate level on the basis of secondary general and secondary vocational education [1$3]$.

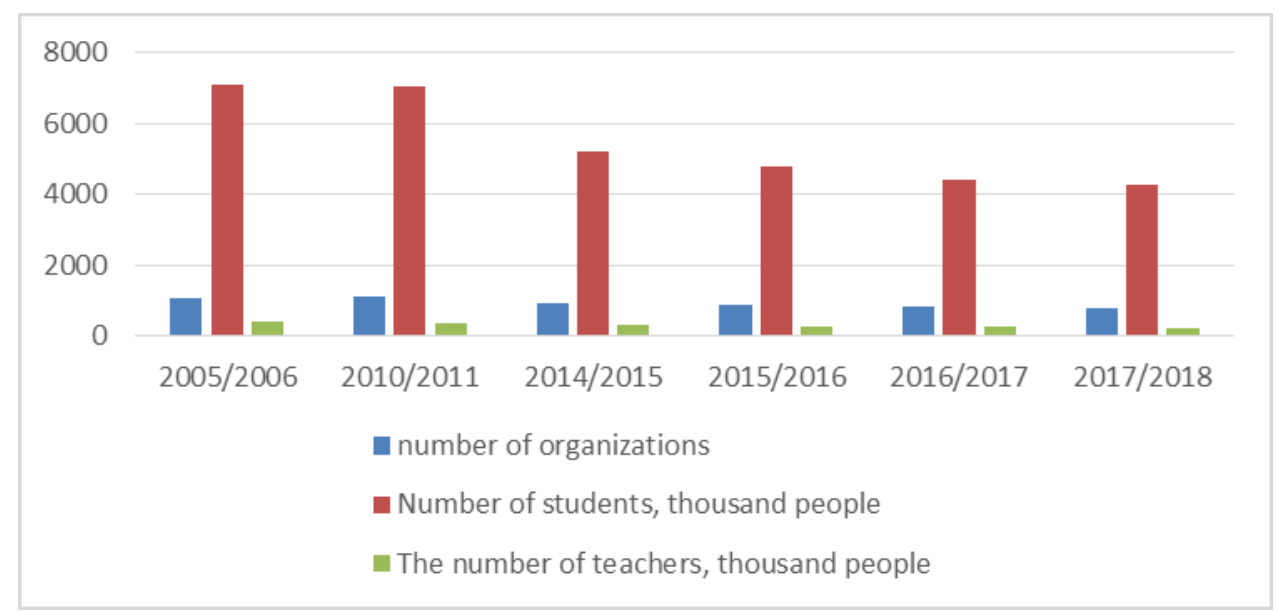

Fig. 1. Dynamics of educational institutions of higher education (Source: www.gks.ru). 


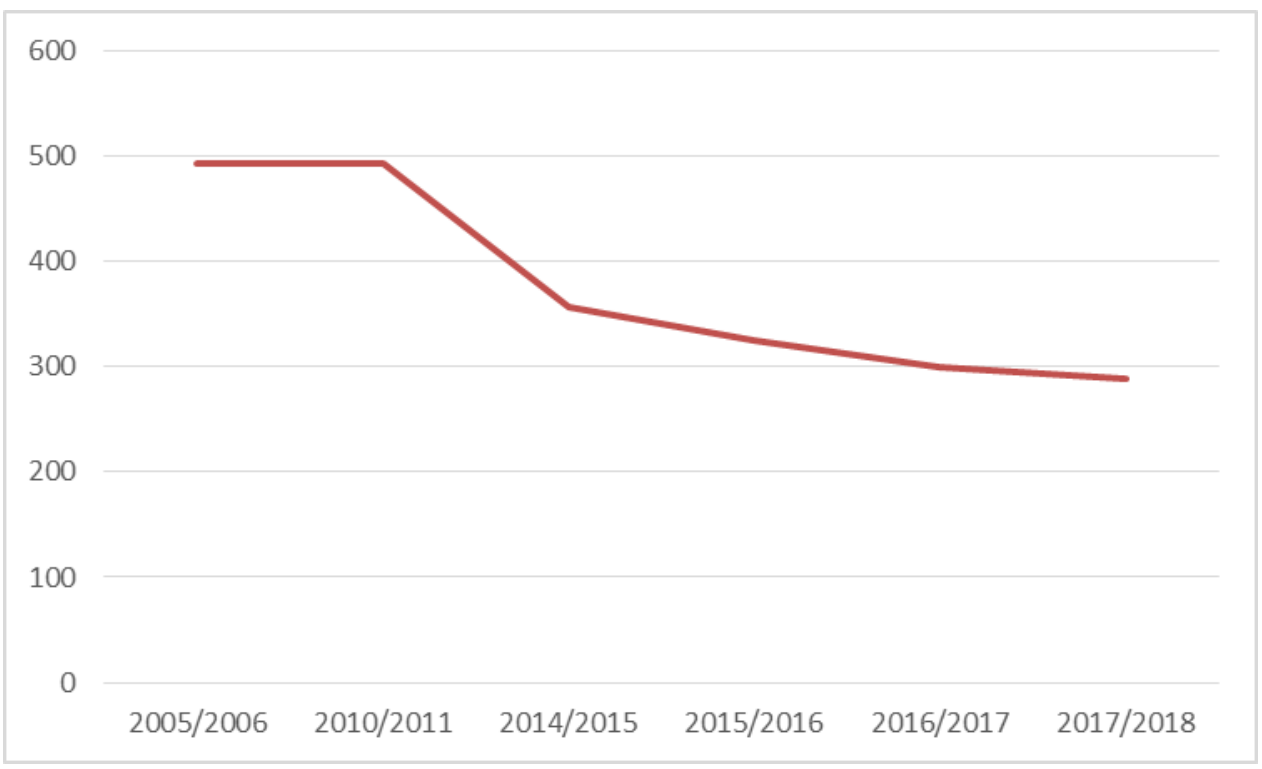

Fig. 2. Number of students enrolled in higher education programs per 10,000 people (Source: www.gks.ru).

The indicators characterizing the number of students enrolled in higher education programs (bachelor's degree, specialty, magistracy) were affected by a decrease of $3.8 \%$ in the population aged 18-25. So, on January 1, 2018, the population of this age was $11,829.3$ thousand people, and on January 1, 2019 - 11384.1 thousand people. In the context of the digitalization of the education sector, the number of students receiving education using distance learning technologies is gradually growing (from $11.3 \%$ in 2018 to $13.1 \%$ in 2019). The education system in Russia is currently undergoing substantial reforms. According to the National Education Project, one of the key objectives of the reform is to ensure the global competitiveness of Russian education and the Russian Federation becoming one of the 10 leading countries in the world in terms of the quality of general education. The national project involves the implementation of 4 main directions of the development of the education system: updating its content, creating the necessary modern infrastructure, training appropriate professional personnel, their retraining and advanced training, as well as creating the most effective mechanisms for managing this area. The project implementation period is 2024, and to date, Russian universities have achieved significant success in entering the world rankings in various subject areas.

\section{Healthcare costs}

One of the main tasks in the socio-economic development of the country associated with the preservation and enhancement of human capital is to ensure the health of the nation. As a socio-economic category, public health is the basis of the country's national wealth and a source of development of its potential. Therefore, the leadership of many countries understands that investment in health also brings income in the long run. The concept of health care costs includes the costs of disease prevention, medical care, diet, and housing.

- disease prevention is a complex of medical and non-medical health-improving measures. An employer interested in greater labor productivity will not skimp on conducting regular 
preventive medical examinations for its employees, the opportunity to visit gyms and pools for free or at a discount, rest in a sanatorium, etc.

- medical care is a series of measures to preserve and strengthen the physical and mental health of a person, to create conditions for his longevity. In case of loss of health, a person is provided with medical assistance. A large role here belongs to medical institutions.

Table 1. Consolidated budget expenditures on health care, average salary of medical workers and the number of doctors per 10,000 people in Russia.

\begin{tabular}{|l|c|c|c|c|c|c|c|}
\hline & $\mathbf{2 0 0 5}$ & $\mathbf{2 0 1 0}$ & $\mathbf{2 0 1 4}$ & $\mathbf{2 0 1 5}$ & $\mathbf{2 0 1 6}$ & $\mathbf{2 0 1 7}$ & $\mathbf{2 0 1 8}$ \\
\hline $\begin{array}{l}\text { The share of health care } \\
\text { costs in the total } \\
\text { expenditures of the } \\
\text { consolidated budget of the } \\
\text { Russian Federation, } \%\end{array}$ & 21.9 & 16.9 & 16.7 & 16.7 & 17.4 & 14.8 & 16.3 \\
\hline $\begin{array}{l}\text { The average monthly } \\
\text { nominal accrued salary of } \\
\text { healthcare workers, rub. }\end{array}$ & 5906 & 15724 & 27068 & 28179 & 29882 & 31980 & 40027 \\
\hline Doctors per 10,000 people & 48.6 & 50.1 & 48.5 & 15.9 & 46.4 & 47.5 & 47.9 \\
\hline
\end{tabular}

In 2018, the national Healthcare project was launched in Russia, the main tasks of which are to reduce the incidence of the population, reduce mortality, and increase life expectancy. It is necessary to eliminate the shortage of medical personnel by increasing their wages, ensuring a massive increase in their qualifications, and also organizing affordable drug provision. All of this can be done by co-financing health care costs by $30 \%$.

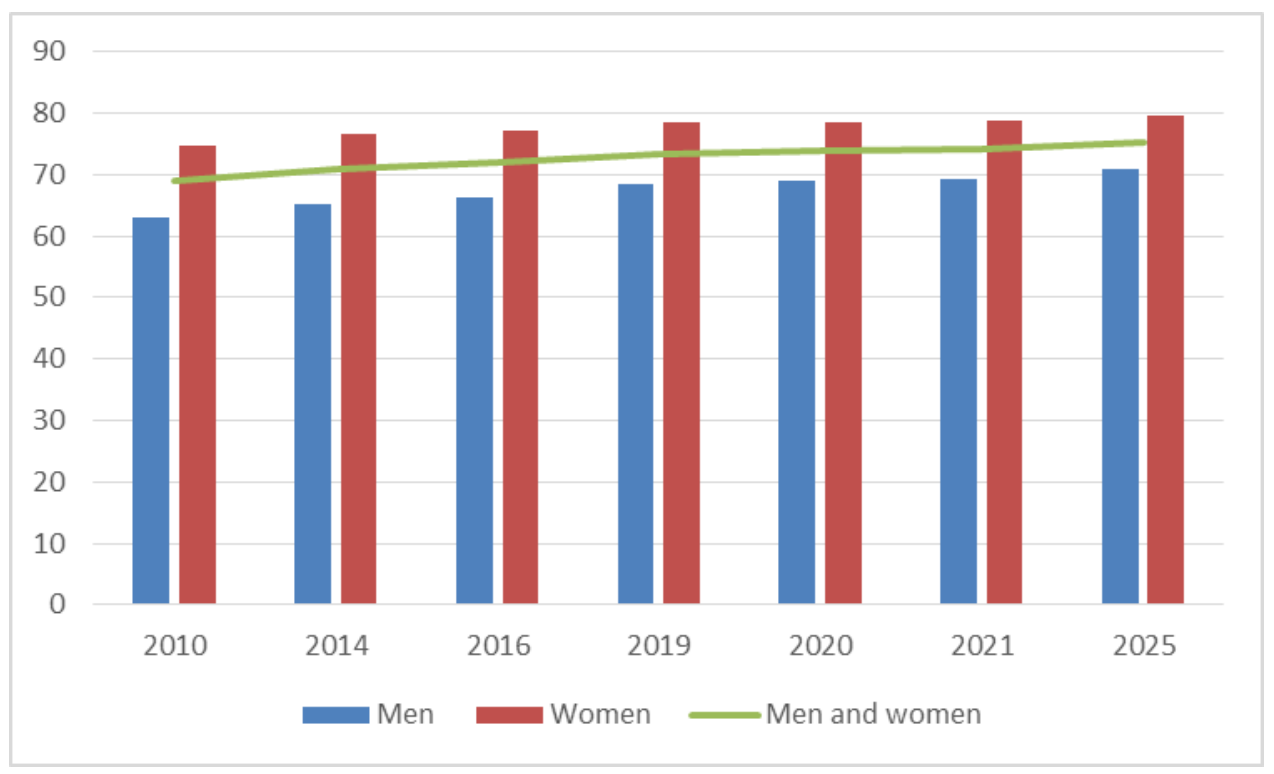

Fig. 3. Life Expectancy in Russia (Source: www.gks.ru).

\section{Research costs}

The country's economic growth largely depends on the scientific community, on the effective reproduction of highly qualified personnel, use - an intellectual resource that can "generate knowledge", turn it into scientific results, advanced technologies. At the federal and regional levels, it is necessary to provide support and assistance to the formation of 
territorial production and economic clusters, to create business incubators, technology parks. The existing high competitiveness in the world market increases the significance and value of investment in scientific research. According to the annual Global Innovation Index, published jointly by Cornell University, the International Business School (INSEAD) and the World Intellectual Property Organization (WIPO), based on their research, the top 5 most innovative countries world in recent years (tab.). The study is based on an analysis of almost 80 indicators and covers various achievements in the field of innovation, patents for the registration of intellectual property, infrastructure, some aspects of human capital are analyzed: expenses for education, scientific publications, etc [4-6].

Table 1. Countries with a high level of innovative development.

\begin{tabular}{|c|c|c|c|c|c|c|c|c|c|}
\hline \multirow{2}{*}{ Country } & \multicolumn{7}{|c|}{ Country rating } \\
\cline { 2 - 9 } & $\mathbf{2 0 1 2}$ & $\mathbf{2 0 1 3}$ & $\mathbf{2 0 1 4}$ & $\mathbf{2 0 1 5}$ & $\mathbf{2 0 1 6}$ & $\mathbf{2 0 1 7}$ & $\mathbf{2 0 1 8}$ \\
\hline \multicolumn{7}{|c|}{5 most innovative countries in the world } \\
\hline Switzerland & 1 & 1 & 1 & 1 & 1 & 1 & 1 \\
\hline Sweden & 2 & 2 & 3 & 3 & 2 & 2 & 3 \\
\hline Singapore & 3 & & & & & & 5 \\
\hline Finland & 4 & & 4 & & 5 & & \\
\hline $\begin{array}{c}\text { Great } \\
\text { Britain }\end{array}$ & 5 & 3 & 2 & 2 & 3 & 5 & 4 \\
\hline Netherlands & & 4 & 5 & 4 & & 3 & 2 \\
\hline USA & & 5 & & 5 & 4 & 4 & \\
\hline
\end{tabular}

High ratings are held by: Switzerland, Sweden, Great Britain, Netherlands, USA, Finland, Singapore. According to the Global Innovation Index, China has demonstrated good innovation potential in recent years, in 2012 it held 34th position, in 2013 - 35th, and in 2018 China entered the top 20 countries with the highest level innovative development, taking 17th position. Despite the fact that the Russian Federation is not included in the 20 leading countries, it is worth noting its success in the field of innovative development. So, in 2012, the Russian Federation occupied 51st position, in 2013 it fell to 62nd, and in 2018 it occupies 46th position in the global innovation rating.

The higher the amount of expenditures by the state in scientific research, the higher the indicators of innovative activity. According to the Organization for Economic Cooperation and Development. Korea and China demonstrate a high and steadily growing dynamics in the intensity of spending on science as a percentage of gross domestic product. 


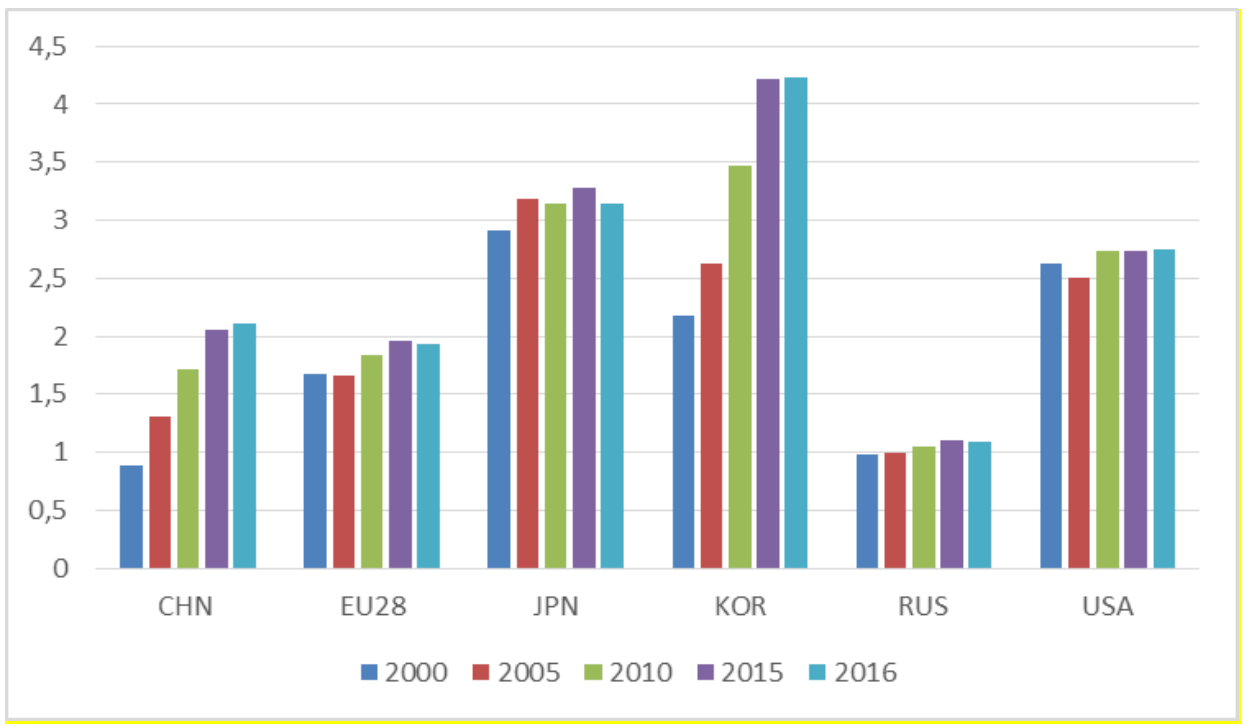

Fig. 4. Research expenditure as \% of GDP (Source: Global Innovation Index).

South Korea is recognized as the most innovative economy in the world and according to the Bloomberg Innovation Index-2018, Russia ranks 25th in this ranking. As you know, the unstable macroeconomic environment, adverse external economic factors, have a significant impact on its innovative activity. We are talking about factors such as inflation, an unstable exchange rate, the imposition of economic sanctions, etc. In addition, low innovative activity indicates that there are reasons for the underutilization of the innovative labor potential of organizations.

Innovative business activity, high labor productivity, and finally economic growth largely depend on "innovative knowledge", which in turn depends on the financing of science in the country.

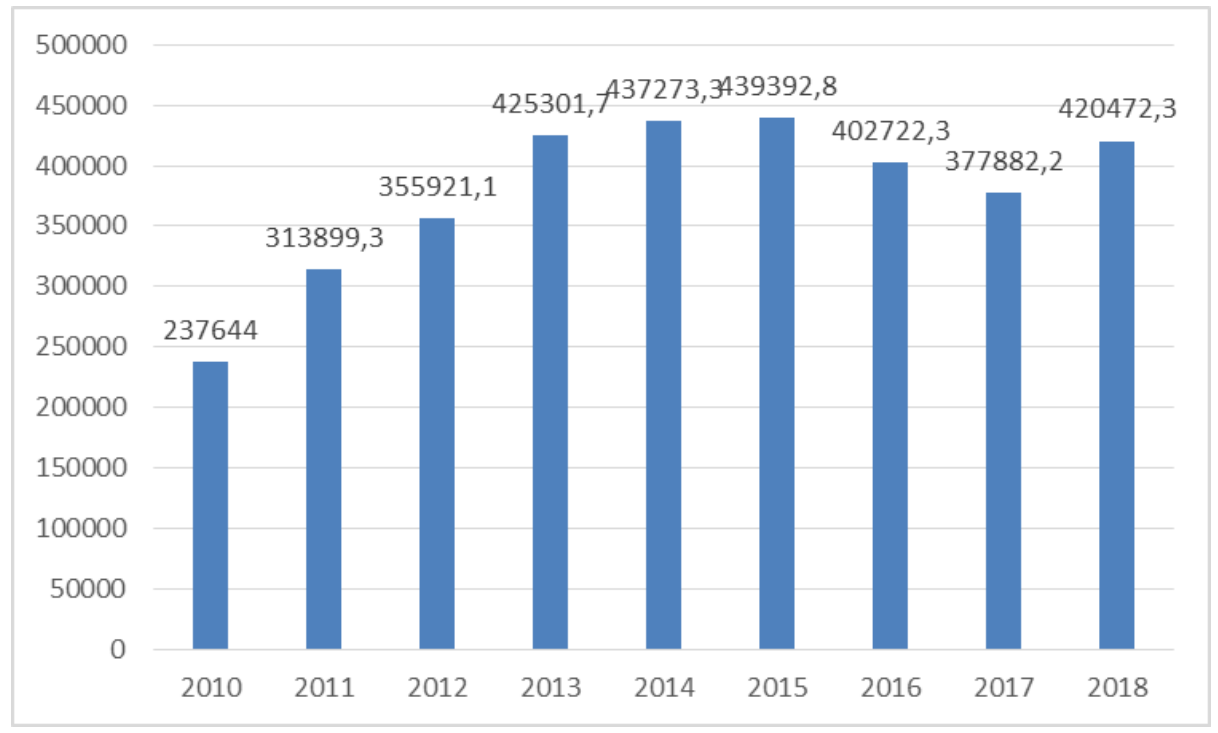

Fig. 5. Financing of science from the federal budget, million rubles (Source: www.gks.ru). 
So, starting from 2000, government spending on basic and applied research in Russia increased annually, up to 2014 (Fig. 5). The reverse dynamics is observed in the expenditures on science to the total expenditures of the federal budget. So, in 2013, expenditures amounted to $3.19 \%$ ( $0.58 \%$ of GDP), in $2014-2.95 \%(0.55 \%$ of GDP), and in $2017-2.30 \%(0.41 \%$ of GDP $)$.

The Ministry of Science and Higher Education in Russia has acute tasks, for example, links between universities, research institutes and enterprises have not yet been worked out, and the reform of the Academy of Sciences has been delayed. It is necessary to untie the knots of contradictions between universities and scientific organizations, to build a system so that reporting does not distract researchers from the main thing. Based on the foregoing analysis of expenditures on education, healthcare and research, this article aims to justify the need to increase investment in human capital, as a key factor in GDP growth and the basis for the development of the national economy.

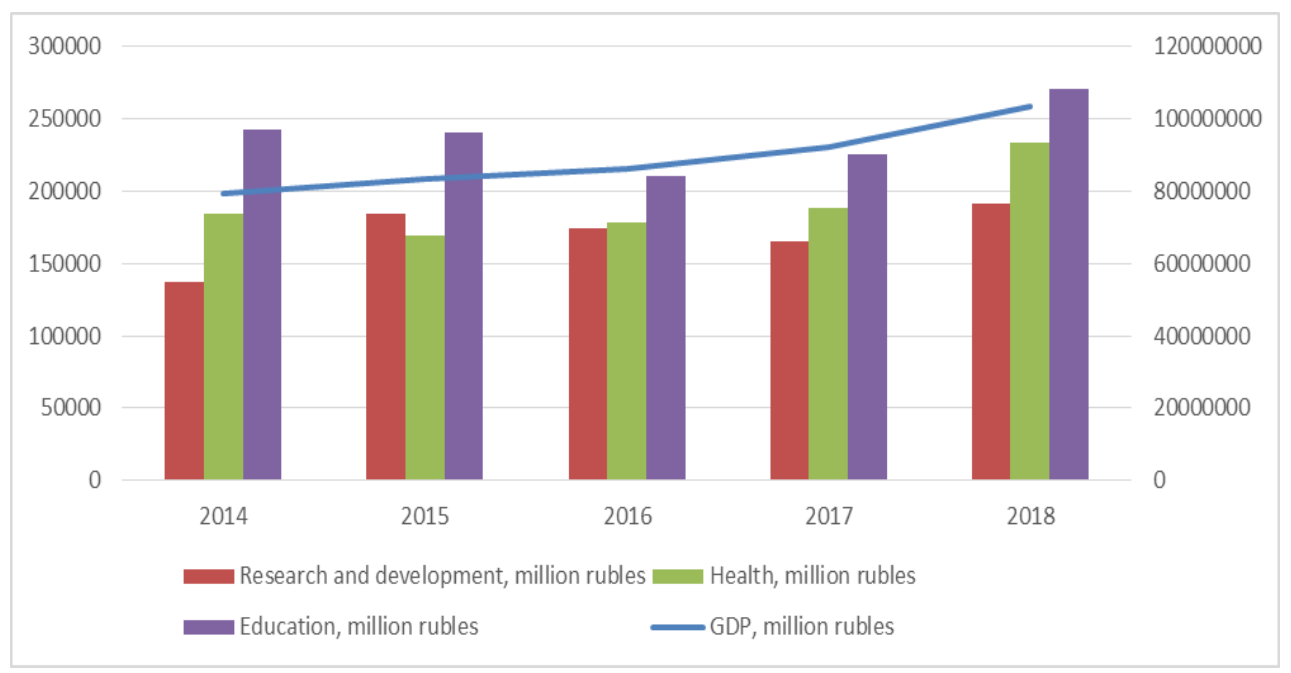

Fig. 6. Dynamics of investment indicators and GDP growth rates (Source: www.gks.ru).

Investments in healthcare, investments in education, and investments in research and development are investigated as indicators of performance. Throughout the study period, there is a close dependence of GDP on investment in human capital. In the table. 2 shows the initial data for the correlation and regression analysis of the impact of investments (Investments in healthcare, Investments in education, Investments in research) on GDP.

Table 2. Dynamics of investments and GDP in Russia (million rubles).

\begin{tabular}{|c|c|c|c|c|}
\hline GDP & $\begin{array}{c}\text { Research and } \\
\text { development }\end{array}$ & Health & Education \\
\hline 2014 & 79200000 & 137300 & 184100 & 242700 \\
\hline 2015 & 83233000 & 184500 & 169200 & 241000 \\
\hline 2016 & 86044000 & 174700 & 178200 & 210500 \\
\hline 2017 & 92089000 & 165300 & 188600 & 225300 \\
\hline 2018 & 103627000 & 191800 & 233400 & 270800 \\
\hline
\end{tabular}


In the table. Figure 3 shows the results of a correlation analysis of the impact of investment on GDP.

Table 3. The results of a correlation analysis of the impact of investment on GDP.

\begin{tabular}{|c|c|c|c|c|c|}
\hline & $Y$ & $X 1$ & $X 2$ & & $X 3$ \\
\hline $\mathrm{Y}$ & 1 & & & & \\
\hline $\mathrm{X} 1$ & 0,65515265 & 1 & & & \\
\hline $\mathrm{X} 2$ & 0,889447596 & 0,371683921 & 1 & & \\
\hline $\mathrm{X} 3$ & 0,536050073 & 0,280583709 & 0,746279616 & & 1 \\
\hline
\end{tabular}

Calculations using the Cheddock scale revealed a high dependence of GDP on investments in health care and research and development.

Fig. 7 shows GDP growth depending on the temporary investment in human capital. Thus, as a result of the correlation analysis, it was concluded that investment in human capital has an impact on GDP growth.

Investments in human capital are certainly effective, but we should not forget that in the calculations it is necessary to take into account the time factor, because this type of investment is a "long effective investment".

Table 4. Regression dependence of GDP on investments in human capital invested "with a difference of one year" (million rubles).

\begin{tabular}{|c|c|c|}
\hline & GDP & Investing in human capital \\
\hline 2014 & 83233000 & 564100 \\
\hline 2015 & 86044000 & 594700 \\
\hline 2016 & 92089000 & 563400 \\
\hline 2017 & 103627000 & 579200 \\
\hline 2018 & 104974000 & 696000 \\
\hline
\end{tabular}

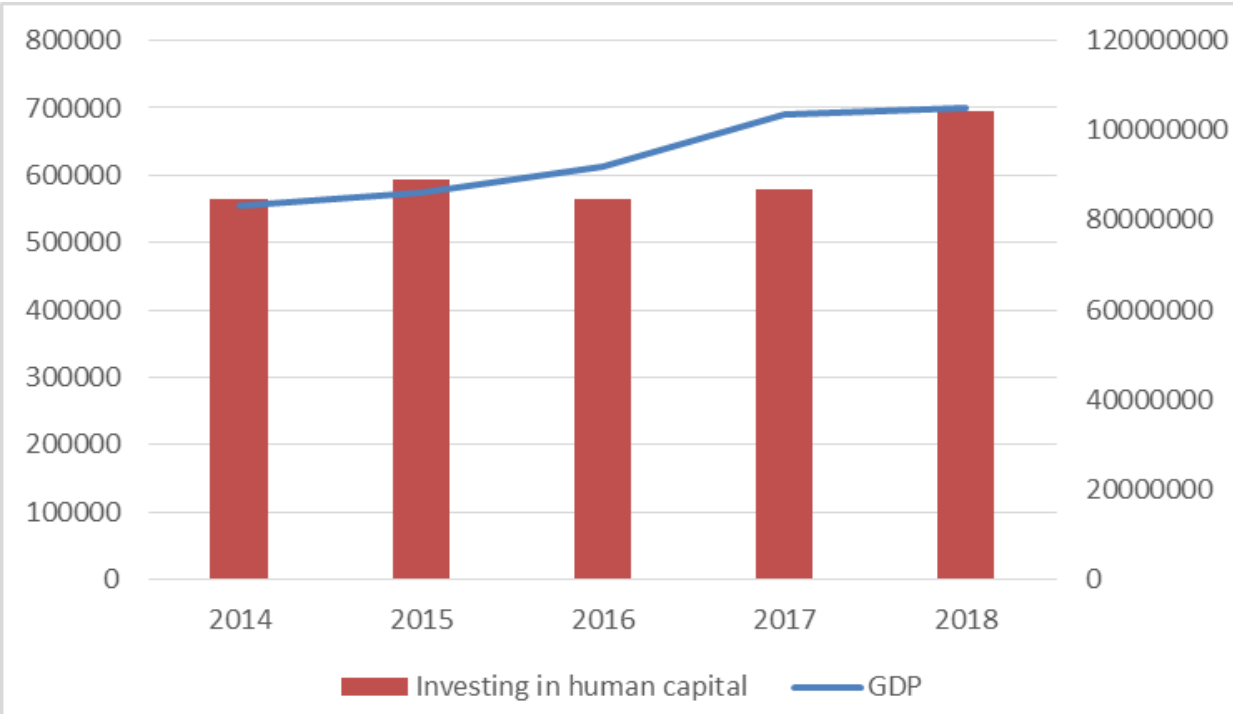


Fig. 7. The dependence of GDP on investment in human capital invested "With a difference of a year" (million rubles) (Source: www.gks.ru).

Human capital is an asset, investing in which provides a future stream of income. The analysis allows us to say that almost all indicators have a greater or lesser effect on GDP, in addition, the development of the national economy involves increasing investment in human capital. In this regard, it seems to us necessary to allocate investments in human capital as a priority of state policy. The special position of investment in human capital is determined by factors arising from its functioning: reproduction of an intellectual product; development of import substitution; transformation of scientific and technological potential; solution to the problem of resource dependence. The Russian experience of investing in human capital shows that the greatest lag behind developed countries is observed in the quality of education, the level of labor productivity, product quality, and the effectiveness of the national economy depend to a greater extent on this. The prospects for national projects launched in 2018 are ensured by the fact that they are personally controlled by the President of the country Vladimir Putin, this is the task of maintaining the country's economic growth at a high level.

\section{Reference}

1. Prognoz dolgosrochnogo social'no-ehkonomicheskogo razvitiya Rossijskoj Federacii na do period $20130 \quad$ goda, http://economy.gov.ru/minec/activity/sections/macro/prognoz/doc20130325_06

2. Federal'naya sluzhba gosudarstvennoj statistiki. EHlektronnyj resurs, http://www.gks.ru

3. I.G. Lukmanova, M.Y. Mishlanova, International Journal of Economics and Financial Issues 5, 208-216 (2015)

4. S. Gasik, Procedia-Social and Behavioral Sciences 226, 351-357 (2016)

5. A.P. Khomenko, S.K. Kargapoltsev, A.V. Eliseev, MATEC Web of Conferences 148, 11004 (2018) https://doi.org/10.1051/matecconf/201814811004

6. V. Dikareva, V. Kankhva, MATEC Web of Conferences 106, 08022 (2017) https://doi.org/10.1051/matecconf/201710608022 